\title{
Enhancement of Cadmium Tolerance in Transgenic Tobacco Plants by Transferring a $\gamma$-glutamylcysteine Synthetase Gene
}

\author{
Songliang Wang ${ }^{1 *}$, Zhiquan Cao' ${ }^{1}$, Yongkuai Chen ${ }^{2}$, Renye $\mathrm{Wu}^{1}$
}

${ }^{1}$ MOE Key Laboratory for Crop Genetics, Breeding and Multiple, Fujian Agriculture and Forestry University, Cangshan, Fuzhou, Fujian province, P.R. China

${ }^{2}$ Fujian Academy of Agricultural Sciences, Gulou, Fuzhou, Fujian Province, P.R. China

"Corresponding author: Songliang Wang, MOE Key Laboratory for Crop Genetics, Breeding and Multiple, Fujian Agriculture and Forestry University; 15 Shangxiadian Rd, Cangshan, Fuzhou, 350002, Fujian province, P.R. China. Email: wsoloedu07@126. com.

Citation: Wang S, Cao Z, Chen Y, Wu R (2017) Enhancement of Cadmium Tolerance in Transgenic Tobacco Plants by Transferring a $\gamma$-glutamylcysteine Synthetase Gene. J Agr Agri Aspect: JAAA-118.

Received Date: 06 May, 2017; Accepted Date: 19 September, 2017; Published Date: 22 September, 2017

\begin{abstract}
Background: $\gamma$-glutamylcysteine synthetase $(\gamma$-GCS) is an important enzyme in the biosynthetic pathway of phytochelatins and plays an important role in the detoxification of heavy metals.

Results: The present work assessed the ability of $\gamma$-GCS transgenic tobacco plants in detoxifying heavy metal cadmium. A $\gamma$-GCS cDNA clone was transformed from the highly cadmium-tolerant plant Pakchoi (Brassica chinensis) into tobacco plants under the control of the $35 \mathrm{~S}$ promoter using the Agrobacterium-mediated leaf disk transformation method. The $\gamma$-GCS gene was successfully transcribed in the transgenic plants, indicated by reverse transcription PCR analysis. To assess heavy metal tolerance, 15 transgenic and 10 non-transgenic plants were grown in pot culture system and challenged with $100 \mu \mathrm{mol} / \mathrm{L}$ of cadmium. Higher cadmium accumulation was found in the transgenic plants than that in the non-transgenic plants. Moreover, more cadmium was accumulated in the roots than in the leaves of the transgenic plants. Analyses of physiological indexes, such as malondialdehyde content, peroxidase activity, superoxide dismutase activity, and proline content, revealed that the transgenic tobacco plants were superior to non-transgenic tobacco plants in resistant physiological indexes.
\end{abstract}

Conclusion: These results indicated that the expression of $\gamma$-GCS enhanced the cadmium accumulation ability as well as resistant physiological indexes of the transgenic tobacco plants.

\section{Abbreviations:}

$\gamma$-GCS : Gamma-Glutamylcysteine Synthetase

GSH : Glutathione

MT : Metallothioneins

PCs : Phytochelatins

PCS : Phytochelatin Synthase

SAT : $\quad$ Serine Acetyltransferase

OASTL : $\quad$ O-acetyl-serine (thiol) lyase

ATP : $\quad$ Adenosine Triphosphate
$\mathrm{Cd}$

SA

JA

ET

ABA

ROS

RT-PCR:

dNTP :

DNA :
Cadmium

Salicylic Acid

Jasmonic Acid

Ethylene

Abscisic acid

Reactive oxygen species

Reverse transcription-polymerase chain reaction Deoxynucleotide

Deoxyribonucleic Acid 


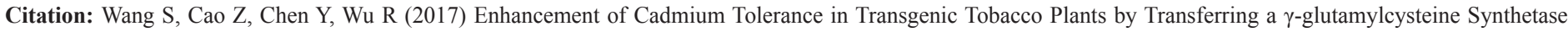
Gene. J Agr Agri Aspect: JAAA-118.

$\begin{array}{lll}\text { RNA } & : & \text { Ribonucleic Acid } \\ \text { PCR } & : & \text { Polymerase Chain Reaction } \\ \text { SOD } & : & \text { Superoxyde Dismutase } \\ \text { NBT } & : & \text { Nitroblue tetrazolium } \\ \text { POD } & : & \text { Peroxidase } \\ \text { MDA }: & \text { Malondialdehyde } \\ \text { TCA }: & \text { Trichloroacetic Acid } \\ \text { EDTA }: & \text { Ethylene Diamine Tetraacetic Acid } \\ \text { ORF } & : & \text { Open Reading Frame } \\ \text { CDNA } & : & \text { Complementary DNA } \\ \mathrm{H}_{2} \mathrm{O}_{2}: & \text { Hydrogen Peroxide }\end{array}$

Keywords: Brassica chinensis; Cadmium hyperaccumulator; $\gamma$-glutamylcysteine synthetase; Heavy-metal Transgenic tobacco

\section{Background}

Globally, agricultural crops are polluted by industrial effluents, which affects crop yield. It is necessary to pay attention to the mechanisms of metal tolerance and accumulation of agricultural crops. Generally, heavy metals such as cadmium, zinc, copper, manganese, and mercury are persistent toxic environmental pollutants [1]. The increasing usage of metal products results in the subsequent accumulation of toxic metals in the environment, which consequently results in serious environmental problems and is ultimately hazardous to human life as a result of the accumulation of metals in the food chain [2,3]. Hence, to overcome this kind of environmental crisis, several researchers have reported various techniques for metal remediation in the environment. Among the methods, phytoremediation is one of the most effective and promising techniques to eliminate heavy metal pollution [4]. As accumulators, plants possess superior properties, such as the capability of autotrophic plants to produce high biomass under low nutrient supply, the capacity to reduce the spread of pollutants through water and wind erosion, and wide-spread public acceptance. Plants also produce many root exudates that support the proliferation of soil microflora that participate in remediation, especially in the rhizosphere, as well as specific chelating agents that mobilize elements into bioavailable forms [5]. With respect to the phytoremediation concept, researchers first selected wild plant accumulators, and approximately five hundred species have been discovered thus far with the capability to accumulate heavy metals, most of which belong to the Brassicaceae family. Although have several advantages over conventional physico-chemical methods and microorganism remediation, wild plants, which often tend to grow slowly and lack the enzymatic mechanism necessary for the efficient metabolization of chelated heavy metals, are not suitable for cleaning up of contaminants [6]. This has led to the idea of modifying plants by the introduction of exogenous gene expression, which may play a role in the process of heavy metal removal or detoxification. The discovery of more innovative catabolic gene transformation technologies is likely important to enhance the phytoremediation efficiency of plants [7].

Phytoremediation is a complex process that includes the solubilization and mobilization of pollutants in the soil, uptake and sequestration into the plant, vascular transport, and tissue distribution in leaf tissue, and transport and sequestration in different organelles of the plant [8-10]. To increase phytoremediation efficiency, the gene expression patterns may only need to target certain cellular compartments and organ types such as the chloroplast [11], vacuole [12], leaf, and root [13] by means of different promoters and targeting signals, or specific responsive promoters under inducible conditions. Many small peptides that have the general structure of ( $\gamma$-Glu-Cys) $n$, known as glutathione (GSH), constitute the complete structure of phytochelatin. These peptides are capable of efficiently sequestrating multiple metal ions in metal-thiolate complexes and play a pivotal role in heavy metal detoxification in plants [14]. Unlike transgenic plants with recombinant Metallothioneins (MTs), the synthesis of Phytochelatins (PCs) contains several enzymatic reactions that occur successively through the synthesis of o-acetylserine from the basic material. Acetyl CoA is then used to synthesize cysteine with $\mathrm{H}_{2} \mathrm{~S}$ in the presence of glutamic acid. Cysteine is catalyzed to form $\gamma$-glutamine homocysteine, and the following synthesis of glutathione requires glutamic acid and glycine bases in addition to $\gamma$-glutamine homocysteine. The monomer of PCs, GSH, is produced by enzymatic reactions, and finally the constitution of PCs is catalyzed by Phytochelatin Synthase (PCS). These synthetic steps of phytochelatins are catalyzed by SAT, OASTL, $\gamma$-GCS, GSHS, and PCS, respectively [15]. $\gamma$-glutamylcysteine synthetase $(\gamma$-GCS) is a rate-limiting enzyme in the PC metabolic pathway, and it can synthesize $\gamma$-glutamylcysteine in the presence of cysteine and ATP, as well as provide the precursor for the synthesis of GSH $[16,17]$. The overexpression of $\gamma$-glutamylcysteine synthetase in plants results in a higher accumulation of GSH and phytochelatins, as well as an enhancement of $\mathrm{Cd}$ tolerance and accumulation $[18,19]$. Overexpression of $\gamma$-GCS can also enhance the defense response of some signaling molecules such as Salicylic Acid (SA), Jasmonic Acid (JA), Ethylene (ET), Abscisic Acid (ABA), and Reactive Oxygen Species (ROS) [20]. The same functional results have been reported for some other genes in the PC pathway [21-23]. It seems that transduction of the exogenous $\gamma$-GCS gene in higher plants has potential for the remediation of heavy metal pollution in the environment. However, studies on the bioremediation of metal pollution using transgenic plants are limited. Hence, in this study, the $\gamma$-GCS gene of Pakchoi (Brassica chinensis) was cloned and transformed into tobacco plants. The tolerance and efficiency of cadmium accumulation by transgenic and non-transgenic plants were determined. Moreover, the physiological properties of the 


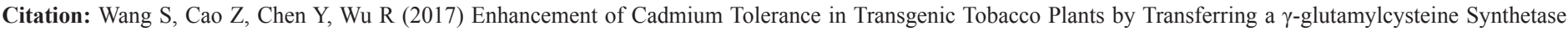
Gene. J Agr Agri Aspect: JAAA-118.

plants, such as the malondialdehyde content, peroxidase activity, superoxide dismutase activity, and proline content, were also determined, and the putative application of transgenic plants for the phytoremediation of heavy metal pollution was successfully reported [22].

\section{Materials and Methods}

\section{Plant materials and growth conditions}

Twelve genotype varieties (A, B, C, ..., K and L) of Pakchoi (Brassica chinensis) were selected for this experiment. Seeds were sown on a plastic plate containing vermiculite, the vermiculite was pre-watered, and each plate had one genotype. There was a total of 12 plates, each of which were covered with plastic film to ensure seed germination. The plates were placed in a greenhouse (16/8 hours of light/dark at $28^{\circ} \mathrm{C}$ ). The plates were irrigated with halfstrength standard Hoagland solution during germination until two leaves were observed on each seedling. After 30 days, the seedlings were transferred into pot culture for plant propagation and irrigated with standard Hoagland solution ( $\mathrm{pH}$ 6.5). The solution $\mathrm{pH}$ was adjusted to 6.5 by adding diluted $\mathrm{HCl}$ or $\mathrm{NaOH}$. The Hoagland solution in the plastic growth containers was renewed every 3 days. After 15 days of hydroponic culture, the Pakchoi plants were transferred into a nutrient solution containing $100 \mu \mathrm{mol} / \mathrm{L}$ of $\mathrm{CdCl}_{2}$ to induce metal stress. The plants were harvested after 6 days of stress culture, and their $\mathrm{Cd}$ contents were determined subsequently with triplicate measurements for each sample.

\section{Isolation of the cDNA conserved sequence of $\gamma$-GCS}

Young leaves of genotype $\mathrm{K}$ (identified as a Cd-tolerant genotype in previous experiments) of $B$. chinensis were collected after $48 \mathrm{~h}$ stress and homogenized using liquid nitrogen. Total RNA was isolated using TRIZOLReagent according to the manufacturer's instructions (TaKaRa, Dalian). The RNA was qualified and stored at $-70^{\circ} \mathrm{C}$ until further use. RT-PCR was conducted using a Reverse Transcription kit according to the manufacturer's instructions (TaKaRa, Dalian). The two PCR primers were constructed from the nucleotide sequence of $\gamma$-GCS from other known Brassica varieties to amplify the conserved sequence; they were the $\gamma$-GCS forward primer (5'- TGATTGTTGCGGCGAGTC-3') and the $\gamma$-GCS reverse primer (5'- CATTCCTATGCGGTCCTT -3'). The reaction contained $2.0 \mu \mathrm{L}$ of buffer, $0.5 \mu \mathrm{L}$ of $10 \mathrm{mM}$ dNTP, $1.0 \mu \mathrm{L}$ of $10 \mathrm{nM}$ of each of the forward and reverse primers, $0.2 \mu \mathrm{L}$ of Taq DNA Polymerase (5U), $1.0 \mu \mathrm{L}(10 \mathrm{ng} / \mu \mathrm{L})$ of template DNA, with a total volume of $20 \mu \mathrm{L}$ in each tube. The reaction conditions were $94^{\circ} \mathrm{C}$ for $5 \mathrm{~min}$, followed by 35 cycles of $94^{\circ} \mathrm{C}$ for $50 \mathrm{~s}, 56^{\circ} \mathrm{C}$ for 1 $\mathrm{min}$, and $72^{\circ} \mathrm{C}$ for $1 \mathrm{~min}$ ). The PCR product was electrophoresed in $1 \%$ agarose gel for $35 \mathrm{~min}$. The target DNA fragment was collected using the Gel Extraction Kit (Sangon, Shanghai) and stored at $-20^{\circ} \mathrm{C}$ until further use.

\section{Cloning the full-length sequence of the $\gamma$-GCS cDNA}

AccordingtothecollectedcDNAconservedsequence of $\gamma$-GCS, the full length $\gamma$-GCS gene was amplified by using the SMARTTM -RACE KIT (Takara, Dalian). Combined with the provided UPM primers, the amplification primers of 3' and 5' end overall length sequences $(\gamma$-GCS 3'-GTCGCTGAGGAAATGGGAATCGGTT, $\gamma$-GCS 5'-ATGCCGAAAGTTGGTTCCC TTGGAC) were designed by software Primer 5.0. Experimental procedures followed manufacturer's instructions (Clontch, USA). After obtaining the 3' and 5' end sequences, Primer 5.0 was utilized to splice the full length of $\gamma$-GCS genes and to design the primers $(\gamma$-GCS-OF 5'- TTCGGATCCCTTCCTTCTTCCTTCACG-3', $\gamma$-GCS-OR 5'- CTCGAGCTCTCACAAACTCACACCTTCTT-3') for the amplification of the full length of $\gamma$-GCS. Restriction enzyme cutting sites BamH I and Sac I were attached to either of the primers for restriction digestion in the following experiments.

\section{Construction and expression of the $\gamma$-GCS gene in a plasmid}

Experimental tobacco (Nicotiana tabacum) K326 seeds were cultivated on solid MS culture medium (standard) in sterile culture bottles. The bacteria used in this experiment are E. coli DH5 $\alpha$ and Agrobacterium tumefactions EHA105. The plasmid pMD-18-T was obtained from the Takara (Dalian) company. The restriction enzymes SmaI and SacI were used to digest the pMD-18T- $\gamma$-GCS and the eukaryotic expression vector pBI 121 at $37^{\circ} \mathrm{C}$ for $16 \mathrm{~h}$. T4 DNA Ligase (obtained from Takara) was used to clone the $\gamma$-GCS fragment into pBI121 overnight. The constructed eukaryotic expression vectors (Fig. 1) were introduced into Agrobacterium tumefaciens strain EHA105.

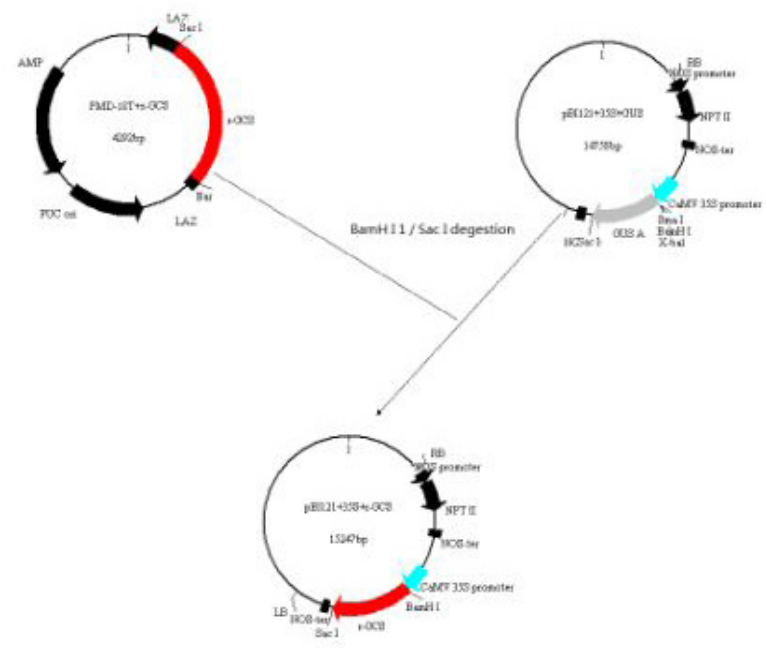

Figure 1: The sketch diagram of the $\gamma$-GCS gene expression vector construction. In order to further verify the result of this vector, restriction sites SmaI and SacI were added in this plasmid. 


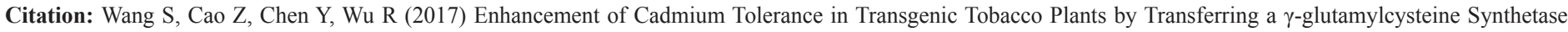
Gene. J Agr Agri Aspect: JAAA-118.

\section{PCR analysis of transgenic plants}

The $\gamma$-GCS gene in EHA105 was transformed into tobacco plants using the Agrobacterium tumefaciens mediated tobacco leaf disc method following $\mathrm{Oh}$ et al. [24]. Transgenic tobacco plants and wild tobacco plants were placed in greenhouse $(16 / 8$ hours of light/dark at $28^{\circ} \mathrm{C}$ ) and irrigated with standard Hoagland solution. After 15 days, these plants were stressed by $100 \mu \mathrm{mol} / \mathrm{L}$ of $\mathrm{CdCl}_{2}$ The leaves and roots of tobacco plants were harvested after 6 days of stress culture. Genomic DNA was isolated from transgenic tobacco according to the method of Edwards et al. [25]. PCR amplification was performed under the following conditions: $94^{\circ} \mathrm{C}$ for $5 \mathrm{~min}, 30$ cycles of $94^{\circ} \mathrm{C}$ for $50 \mathrm{~s}, 62^{\circ} \mathrm{C}$ for $1 \mathrm{~min}$, and $72^{\circ} \mathrm{C}$ for $1 \mathrm{~min}$. Finally, the PCR products were separated using $1 \%$ agarose gel electrophoresis, and then extracted and stored at $-18^{\circ} \mathrm{C}$ for further use.

\section{Gene expression analysis by semi-quantitative RT-PCR}

RNA was extracted from tobacco leaves and reverse transcribed into cDNA. A 1- $\mu$ l cDNA template sample was used to amplify the target genes and the actin gene by semi-quantitative PCR amplification, and the numbers of cycles were 28 and 26, respectively. After the PCR amplification, the amplified RNA gene and actin RNA gene samples were mixed and $10 \mu \mathrm{l}$ of the mixed samples were separated by $2.5 \%$ agarose gel electrophoresis and observed using $2 \mu \mathrm{l}$ of bromophenol blue as an indicator; photographs were documented with gel imaging systems. The one gel quantification software was used for density scanning of the electrophoretic bands. The contrast and brightness of the target genes of $\gamma$-GCS and the actin gene bands were analyzed, and the transcription level of expression was based on a brightness ratio.

\section{Determination of cadmium content}

The metal concentration in the plant tissues was analyzed using an atomic absorption spectrophotometer method. In brief, a standard cadmium solution was prepared by dissolving 1.000 $\mathrm{g}$ of cadmium in a small amount of hydrochloric acid. Then, the solution was diluted in $1 \%$ hydrochloric acid made up to 1 L. To determine the cadmium concentration in the leaf and root of the tobacco plant, these tissues were cleaned using water, and weighed. An appropriate amount of the tobacco plant was dried in an oven at $70^{\circ} \mathrm{C}$ overnight. The dried plant materials were ground into a powder using a mortar and pestle. Concentrated nitric acid $(10 \mathrm{ml})$ was added to $1 \mathrm{~g}$ of dried plant samples in a small beaker and digested overnight, after which the beaker was carefully laid on a heating plate until red-brown nitrogen dioxide gas was no longer produced. After the beaker cooled, a small amount of 70\% perchloric acid was added. The beaker was reheated to evaporate the liquid to a smaller volume. Then, the sample solution was dissolved in a $50-\mathrm{ml}$ flask that contained a specific volume of deionized water. The cadmium concentration in the transgenic and non-transgenic tobacco plant tissues was calculated by substitution of sample absorptions in a curvilinear equation $\left(\mathrm{y}=0.1769^{*} \mathrm{x}+\right.$ 0.0118 ) of a cadmium standard solution, where ' $x$ ' denotes the sample absorption. Cadmium contents were determined with triplicate measurements for each sample.

\section{Physiological index of transgenic tobacco plants}

\section{Superoxide Dismutase (SOD)}

Tobacco leaves $(0.5 \mathrm{~g})$ were homogenized using quartz sand and $1 \mathrm{ml}$ of ice-cold $0.05 \mathrm{M} \mathrm{pH} 7.8$ phosphate buffer in an ice bath. Then, the homogenous enzyme solution was transferred into a $5-\mathrm{ml}$ centrifuge tube and made up to a final volume of $5 \mathrm{ml}$ by adding phosphate buffer. The enzyme solution was maintained at $60^{\circ}$ cin a water bath for $15 \mathrm{~min}$, cooled for several minutes, and then centrifuged at $10000 \mathrm{r} / \mathrm{min}$ for $20 \mathrm{~min}$, after which the enzyme solution of the supernatant was collected for the enzyme assay. This step was repeated three times. The NBT photoreduction method was used in the SOD assay. The SOD enzyme reaction mixture consisted of $5.4 \mathrm{ml}$ of reaction liquid, $0.1 \mathrm{ml}$ of enzyme solution, and $0.5 \mathrm{ml}$ of riboflavin. The blank control consisted of $5.4 \mathrm{ml}$ of reaction liquid, $0.1 \mathrm{ml}$ of distilled water, and $0.5 \mathrm{ml}$ of riboflavin. The blank control was kept under dark conditions; the other test tubes were kept under $4000 \mathrm{~lx}$ light for $20 \mathrm{~min}$. Prior to measuring the absorbance of the sample at $560 \mathrm{~nm}$, the initial value was adjusted to zero using the blank control. Subsequently, the sample absorbance was measured at $560 \mathrm{~nm}$. SOD enzyme activity was calculated using the following formula: SOD (U/g $\mathrm{FW})=(\mathrm{ACK}-\mathrm{AE}) * \mathrm{VT} / \mathrm{Ack} / 0.5 / \mathrm{W} / \mathrm{Vs}$ (where $\mathrm{VT}$ is the total volume of the enzyme solution (ml); VS is the used volume of the enzyme solution ( $\mathrm{ml})$; $\mathrm{W}$ is the fresh weight of the tobacco leaves (g); ACK is the absorbance of the buffer solution substitute for the enzyme solution; and $\mathrm{AE}$ is the absorbance of the sample tubes). SOD value was determined with triplicate measurements for each sample.

\section{Peroxidase (POD)}

Tobacco leaves $(0.5 \mathrm{~g})$ were ground into a uniform pulp by adding a small amount of quartz sand and $1 \mathrm{ml}$ of $0.05 \mathrm{M}$ phosphate buffer ( $\mathrm{pH}$ 6.0); the homogenate of the enzyme solution was transferred into a 5-ml centrifuge tube and phosphate buffer was added to a final volume of $5 \mathrm{ml}$. The enzyme solution was centrifuged at $4000 \mathrm{r} / \mathrm{min}$ for $15 \mathrm{~min}$ and the supernatant was collected for the enzyme assay. The experiments were conducted in triplicate. The enzyme solution boiled for $5 \mathrm{~min}$ was considered as the control group. After adding the enzyme solution, the reaction mixture was immediately immersed in a water bath at $34^{\circ} \mathrm{C}$ for $3 \mathrm{~min}$, after which the solution was rapidly diluted to half concentration. The absorbance was recorded at one-second intervals at $470 \mathrm{~nm}$ using a colorimeter. The absorbance data were recorded five times at the respective intervals. The enzyme activity 
was determined by analyzing the variation in the absorbance between the one-second intervals. One unit of enzyme activity was expressed as the variation in the absorbance at $470 \mathrm{~nm}(0.01)$ in one second. The calculation formula was as follows: Activity of peroxidase $=\Delta \mathrm{A} 470 * \mathrm{VT} / \mathrm{W} / \mathrm{VS} / 0.01 / \mathrm{t}(\mathrm{VT}$ is the total volume of the enzyme solution $(\mathrm{ml})$; VS is the used volume of the enzyme solution ( $\mathrm{ml})$; W is the fresh weight of the tobacco leaves $(\mathrm{g})$; $\Delta \mathrm{A}_{470}$ is the variation in the absorbance between each second; $t$ is the reaction time). POD value was determined with triplicate measurements for each sample.

\section{Malondialdehyde (MDA)}

Tobacco leaves $(0.5 \mathrm{~g})$ were ground into a uniform pulp by adding a small amount of quartz sand and $5 \mathrm{ml}$ of $5 \%$ TCA, followed by centrifugation at $3000 \mathrm{rpm} / \mathrm{min}$ for $10 \mathrm{~min}$. Then, two $\mathrm{ml}$ of the supernatant was collected and added to $2 \mathrm{ml}$ of $0.67 \%$ TBA, mixed and placed in boiling water for $30 \mathrm{~min}$, after which the samples were cooled and centrifuged again. This was repeated three times. The absorbance of the supernatant was determined at $450 \mathrm{~nm}, 532 \mathrm{~nm}$, and $600 \mathrm{~nm}$. The MDA concentrations of the solution and plant tissue were calculated using the following formula: $\mathrm{A}_{532}-\mathrm{A}_{600}=155000^{*} \mathrm{C} * \mathrm{~L}$; Error correction formula: $\mathrm{C} /$ $\mu \mathrm{mol} / \mathrm{L}=6.45\left(\mathrm{~A}_{532}-\mathrm{A}_{600}\right)-0.56 \mathrm{~A}_{450}\left(\mathrm{~A}_{450}, \mathrm{~A}_{532}, \mathrm{~A}_{600}\right.$ indicate the absorbance at $450 \mathrm{~nm}, 532 \mathrm{~nm}$, and $600 \mathrm{~nm}$, respectively; $C$ is the MDA concentration of the extraction solution; $\mathrm{L}$ is the thickness of the cuvette). MDA value was determined with triplicate measurements for each sample.

\section{Proline}

The different plant leaves $(0.5 \mathrm{~g})$ were accurately weighed for proline analysis. The leaf samples were added to $5 \mathrm{ml}$ of $3 \%$ sulfosalicylic acid solution in glass tubes. The tubes were heated in a boiling water bath for $10 \mathrm{~min}$ with frequent shaking. After cooling, the samples were filtered into clean test tubes, and this filtrate was considered as the proline extract. The extract $(2 \mathrm{ml})$ was withdrawn and placed in another clean test tube with a glass stopper, and $2 \mathrm{ml}$ of glacial acetic acid and $2 \mathrm{ml}$ of acidic indene ninhydrin reagent were added and heated in a boiling water bath for $30 \mathrm{~min}$ until the solution turned red. Then, $4 \mathrm{ml}$ of toluene was added and the solution was shaken for $30 \mathrm{~s}$, placed aside and allowed to stand for a moment, and then $10 \mathrm{ml}$ of the upper liquid was transferred into centrifuge tubes and centrifuged at 3000 rpm for 5 min. A straw was used to gently draw the upper red proline toluene solution into the cuvette; toluene was used as a blank control, and the absorbance value was read at a wavelength of $520 \mathrm{~nm}$ using a spectrophotometer. A regression equation (or the standard curve) was used to calculate the proline content in $2 \mathrm{ml}$ of the liquid $(\mathrm{x} \mu \mathrm{g} / 2 \mathrm{ml}$ ), and then the proline percentage of the samples was calculated. The calculation formula is as follows: proline content per unit fresh weight sample $(\mu \mathrm{g} / \mathrm{g})=\mathrm{X} * 5 / 2] /$ $\mathrm{W} / 106^{*} 100 \%$ ( $\mathrm{X}$ is the proline content in $2 \mathrm{ml}$ of solution; $\mathrm{W}$ is the fresh weight of the samples). Proline was determined with triplicate measurements for each sample.

\section{Glutathione (GSH)}

Leaf samples $(2.5 \mathrm{~g})$ were placed in a mortar to which $5 \mathrm{ml}$ of pre-cooled TCA $\left(4^{\circ} \mathrm{C}\right.$; containing $5 \mathrm{mmol} / \mathrm{L} \mathrm{Na}$-EDTA) was added, and the samples were ground into a homogenate in an ice bath. The samples were centrifuged at $4^{\circ} \mathrm{C}, 12000 \mathrm{rpm}$, for $20 \mathrm{~min}$ and the supernatants were collected for determination of the GSH content following the method referred to in the Laboratory Manual Guidance of Plant Physiology Module [26]. and repeated three times. GSH value was determined with triplicate measurements for each sample.

\section{Results}

\section{Isolation and characterization of full-length $\gamma$-GCS}

The full-length nucleotide sequence and the deduced amino acid sequence of $\gamma-G C S$ cloned in our experiment are shown in Figure 2. According to the sequence results of the 3 ' and 5' end of the $\gamma$-GCS gene, combined with the encoded sequence of the target gene, and using counting software to splice the nucleotide sequence, we obtained a full-length gene with 1838 bp (Figure 2 and Figure 3) (Genbank accession No. GQ996585). The open reading frame of $\gamma$-GCS is $1536 \mathrm{bp}$. Results of the amino acid P-BLAST analysis of the $\gamma$-GCS gene (Genbank accession No. ACX70134.1) coding region showed that there is homology between the cabbage $\gamma$-GCS gene and other species; the homology with Indian mustard $\gamma$-GCS (Brassica juncea, Genbank accession number: CAD91713.1) is 99\%, and with Brassica napus $\gamma$-GCS (Brassica napus, Genbank accession number: CAK24967.1) is $97 \%$. The subtle differences in the amino acid sequence maybe due to the differences between species within the same genus; the amino acid homology with Cruciferous plants, such as Arabidopsis (Arabidopsis Log number: CAA71075.1) $\gamma$-GCS, was approximately $90 \%$.

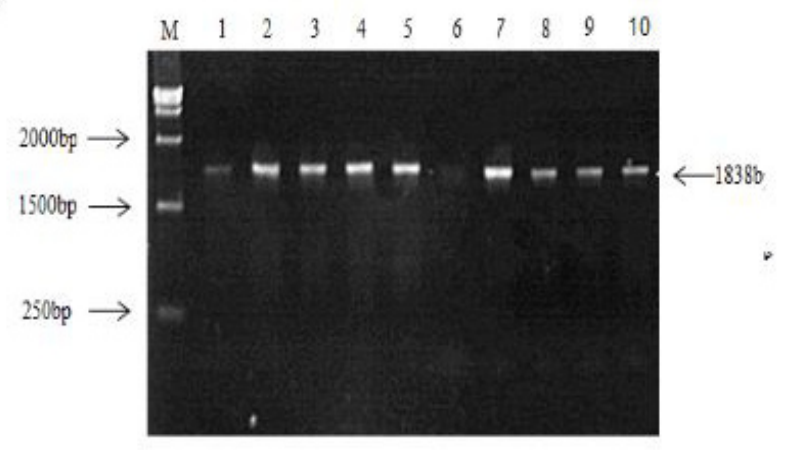

Figure 2: The PCR amplification result of $\gamma$-GCS gene in Brassica rapa var. chinensis. Notes: 1) Lane M:DNA Marker 15000; Lane 1-10: The full-length of the $\gamma$-GCS gene. 2) The DNA templates used in this PCR were isolated from ten different Brassica chinensis plants 


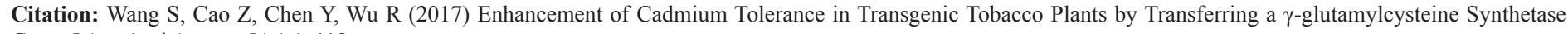
Gene. J Agr Agri Aspect: JAAA-118.

Translation of DNAMAN1 (1-1536)

Total amino acid number: 511, MW=57475

Max ORF starts at AA pos 1 (may be DNA pos 1) for 511 AA (1533 bases), MW=57475

CGCGGGGTCTTCCTTCTTCCTTCACGAGATTCAGGAAACACACC

1 ATGGCGTTATTGTCTCAGGCAGGAGGAGCATACACTGTCCCTTCCGGACACGTAAGCTCA

1 M A L L S Q A G G A Y T V P S G H V S S

61 AAGATCAGGACTACTTCAGTTTCTGGTTGTGTAAGAAATTTGAGGATGAGTGAAGCTTAT

21 K I R T T S V S G C V R N L R M S E A Y

121 GTTAGCTCCTACTCCAGGACTCTCTCTACCAACTCAAGGAGCAAGAGAGGTCATCAGTTG

41 V S S Y S R T L S T N S R S K R G H Q L

181 ATTGTTGCGGCAAGTCCTCCTACAGAGGAAGCTGTAGTTGCCACTGAGCCGCTTACGAGA

61 I V A A S P P T E E A V V A T E P L T R

241 GAGGATCTCATTGCTTATCTTGCCTCCGGATGCAAATCAAAGGACAAATGGAGGATAGGT

81 E D L I A Y L A S G C K S K D K W R I G

301 ACAGAACATGAGAAGTTTGGTTTTGAGGTTAATACTTTACGTCCTATGAAGTATGAACAA

101 T E H E K F G F E V N T L R P M K Y E Q

361 ATAGCTGAGCTGCTTAACAGCATCGCCGAGAGGTTTGAATGGGAGAAAGTATTGGAAGGT

121 I A E L L N S I A E R F E W E K V L E G

421 GACAAGATCATTGGTCTCAAGCAGGGGAAACAAAGCATTTCACTTGAGCCTGGTGGTCAA

141 D K I I G L K Q G K Q S I S L E P G G Q

481 TTTGAGCTTAGTGGTGCGCCTCTTGAGACTTTGCACCAAACTTGTGCTGAAGTCAACTCA

161 F E L S G A P L E T L H Q T C A E V N S

541 CATCTTTATCAGGTCAAAGCTGTCGCTGAGGAAATGGGAATCGGTTTCTTAGGAATGGGT

181 H L Y Q V K A V A E E M G I G F L G M G

601 TTCCAGCCCAAATGGCGTCGTGAGGACATTCCCATCATGCCTAAGGGGAGATACGACATT

201 F Q P K W R R E D I P I M P K G R Y D I

661 ACGAGAAACTACATGCCGAAAGTTGGTTCCCTTGGACTTGATATGATGCTTCGGACCTGT

221 T R N Y M P K V G S L G L D M M L R T C

721 ACTGTTCAGGTGAATCTGGATTTTAGCTCAGAAGCTGATATGATCAGGAAGTTTCGTGTT

241 T V Q V N L D F S S E A D M I R K F R V

781 GGTCTTGCCTTGCAACCTATAGCAACGGCTCTGTTTGCAAATTCCCCTTTCACCGAAGGA

261 G L A L Q P I A T A L F A N S P F T E G

841 AAGCCAAACGGGTTCCTCAGCATGAGAAGCCATATATGGACAGACACTGACAAGGACCGC

281 K P N G F L S M R S H I W T D T D K D R

901 ACAGGAATGCTACCGTTTGTTTTCGATGACTCTTTTGGGTTTGAGCAGTATGTTGACTAC

301 T G M L P F V F D D S F G F E Q Y V D Y

961 GCACTGGATGTTCCTATGTACTTCGCCTACCGAAACAACAAATACGTGGACTGTACTGGA

321 A L D V P M Y F A Y R N N K Y V D C T G 


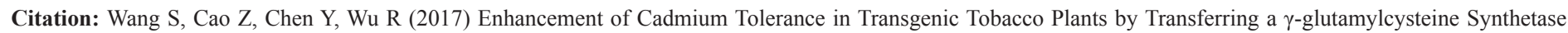
Gene. J Agr Agri Aspect: JAAA-118.

1021 ATGACATTTAGGCAATTTTTAGCTGGAAAGCTTCCTTGCCTCCCAGGTGAACTGCCTACA

341 M T F R Q F L A G K L P C L P G E L P T

1081 TATAATGATTGGGAAAATCATCTGACGACAATATTCCTTGAGGTTCGGTTGAAGAGATAC

361 Y N D W E N H L T T I F L E V R L K R Y

1141 ATGGAGATGAGAGGCGCTGATGGAGGTCCCTGGAGGAGGTTGTGCGCCCTTCCAGCTTTC

381 M E M R G A D G G P W R R L C A L P A F

1201 TGGGTGGGTTTGTTCTATGATGAGGACGTTCTCCAAGCTGCCTTGGATCTGACAGCTGAC

401 W V G L F Y D E D V L Q A A L D L T A D

1261 TGGACTCCAGCAGAAAGAGAGATGCTAAGGAACAAAGTTCCAGTAACTGGTTTAAAGACA

421 W T P A E R E M L R N K V P V T G L K T

1321 CCGTTTAGAGATGGTTTGTTGAAGCATGTGGCTGAAGATGTCCTGAAACTCGCAACGGAT

441 P F R D G L L K H V A E D V L K L A T D

1381 GGTCTAGAGCGTAGGGGATACAAGGAAGCTGGTTTCTTGAACGCTCTCACTGAAGTGGTC

461 G L E R R G Y K E A G F L N A L T E V V

1441 AGAACAGGAGTTACACCGGCGGAGAATCTCTTGGAAATGTACAATGGAGAATGGGGACAA

481 R T G V T P A E N L L E M Y N G E W G Q

1501 AGCGTAGACCCTGTGTTCCAGGAACTGCTGTACTAA

501 S V D P V F Q E L L Y *

AGGTTGACATGAGAACAAGAAGGTGTGAGTTTGTGAAACCTGAAGAACTCAAAGTCTCTCATGAATAAGGTTTTTTTATTTGTTGCAATCCGGATTTGAGAACTGATTTTATTTTCTTTTGAAATTTGAAGCTGTGAAAAATAAAAATATGTACTAACGATTTCGATATGGGGAAATCGTCAGGGAAGTTGCAGTGTTTGGATCTTTGAATAAAATTTACCCATTTTTTTGAAAAAAAAAAAAAAAAAAAAAAAAAAA

Figure 3: Nucleotide sequence and deduced amino acid sequence of $\gamma$-GCS. Start codon and stop codon are indicated by boxes. Primers of $\gamma$-GCS -QF and $\gamma$-GCS -OR are shown using gray boxes.

\section{Generation of $\gamma$-GCS transgenic tobacco plants}

In order to evaluate the effects of $\gamma$-GCS on heavy-metal accumulation, the Pakchoi (Brassica chinensis) $\gamma$-GCS cDNA, under control of the 35S promoter, was transformed into tobacco plants (Figure 4). The transgenic tobacco seedlings were placed in (16/8 hours of light/dark at $28^{\circ} \mathrm{c}$ ) (Figure 5). The tested tobacco line showed amplification of the expected $1536 \mathrm{bp}$ band after PCR using genespecific primers (Figure 6). Expression of $\gamma$-GCS in transgenic lines was confirmed by semi-quantitative RT-PCR analysis. The results showed that the $\gamma$-GCS gene was successfully expressed in tobacco plants (Figure 7). 
Citation: Wang S, Cao Z, Chen Y, Wu R (2017) Enhancement of Cadmium Tolerance in Transgenic Tobacco Plants by Transferring a $\gamma$-glutamylcysteine Synthetase Gene. J Agr Agri Aspect: JAAA-118.

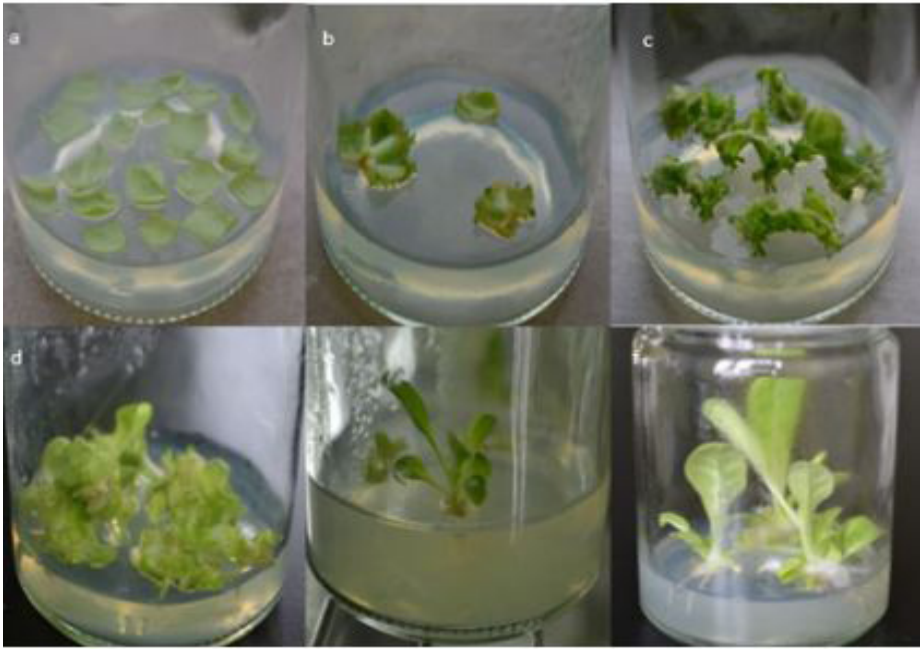

Figure 4: Resistant transgenic tobacco plants. Note: Transgenic tobacco plants were obtained by the Agrobacterium tumefaciens mediated tobacco leaf disc method, the pictures in this figure represent the process: a. Tobacco leaf discs' pre-culture; b. Co-cultivation of tobacco leaf discs and $\gamma$-GCS transgenic A. tumefaciens EHA105; c. Using carbenicillin to eliminate $A$. tumefacien and using kanamycin to select transgenic tobacco buds; d. Induction of transgenic tobacco buds' generation; e. Transplant transgenic tobacco buds to rooting media; d. Induction of rooting. Culture bottles were placed in greenhouse $\left(16 / 8\right.$ hours of light/dark at $\left.28^{\circ} \mathrm{c}\right)$.

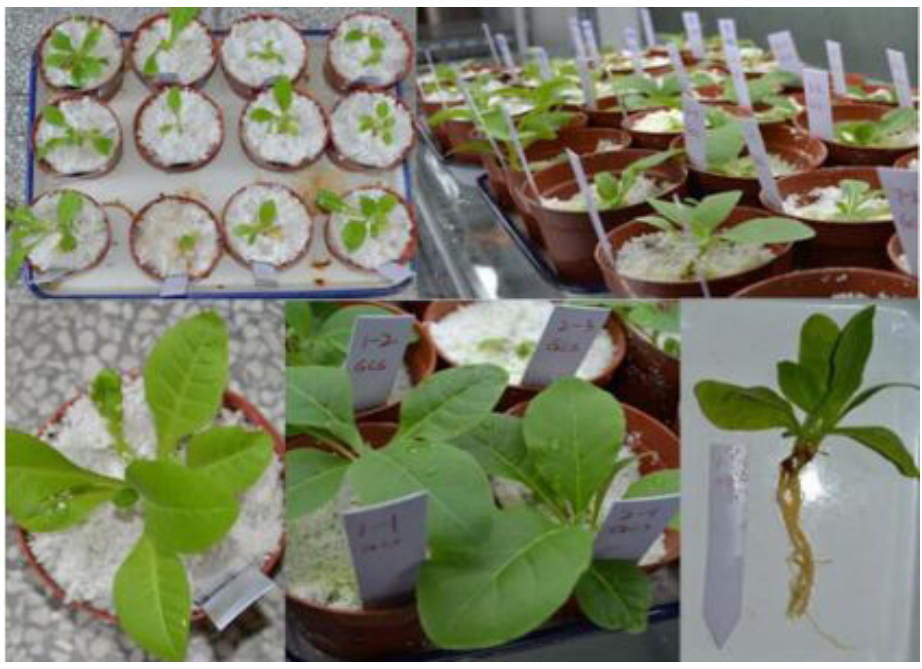

Figure 5: Transgenic tobacco plants cultivated in greenhouse. Note: The potted tobacco plants were placed in greenhouse (16/8 hours of light/dark at $28^{\circ} \mathrm{c}$ ). During this period, PCR method was applied to select positive $\gamma$-GCS transgenic tobacco plants. Cadmium stress $(100 \mu \mathrm{mol} / \mathrm{L})$ was applied to tobacco plants after 15 days. The roots and leaves of tobacco plants were harvested separately after 6 days' stress.

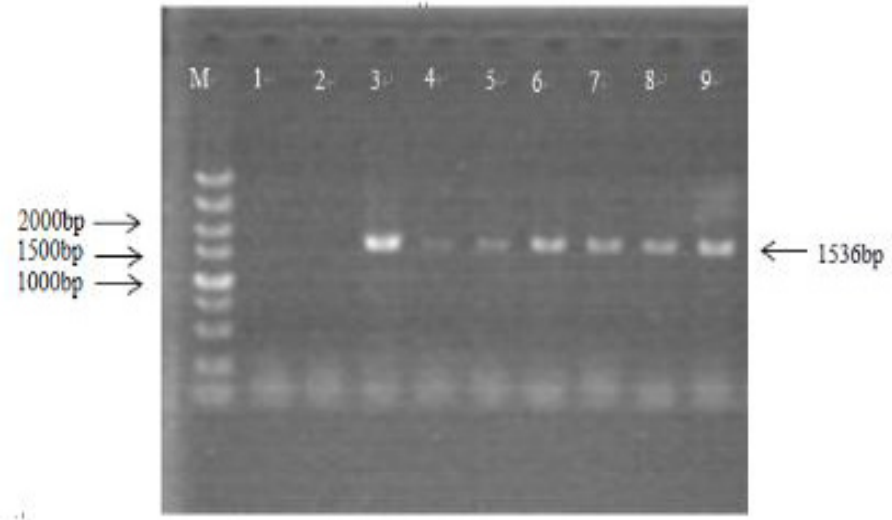

Figure 6: Amplification result of $\gamma$-GCS genetically modified tobacco. Notes: 1) Lane M: DNA Marker 10000; Lane 1: Blank control; Lane 2: Wild tobacco control; Lane 3-9: Positive $\gamma$-GCS transgenic tobacco PCR amplification products.2) The DNA templates of reactions 3 to 9 were isolated from different tobacco plants.

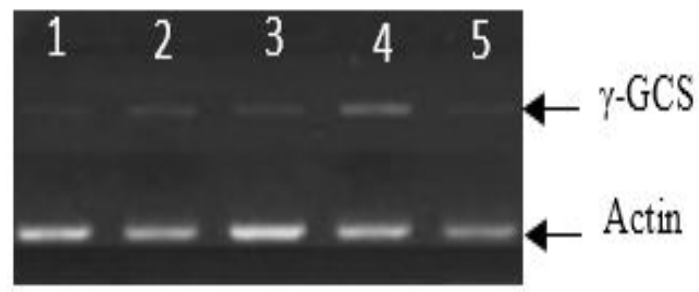

Figure 7: Electrophoretogram of RT-PCR detection of $\gamma$-GCS in transgenic tobacco Note: The RT-PCR result indicates, from the transcriptional level, that the $\gamma$-GCS gene was not only integrated into tobacco plant, but also expressed in tobacco plant.

\section{$\gamma$-GCS transgenic tobacco accumulates more $\mathrm{Cd}$ than wild tobacco plants}

The Cd contents of the transgenic tobacco plants and corresponding wild ones were shown in Figure 8. Generally, the expression of the $\gamma$-GCS gene enhanced the accumulation capability of $\mathrm{Cd}$ in tobacco plants. In this study (Table 2), the accumulation of $\mathrm{Cd}$ in the roots and leaves of wild tobacco plants was $20.88 \mu \mathrm{g} / \mathrm{g}$ and 9.95 $\mu \mathrm{g} / \mathrm{g}$ (in dry weight), respectively. The $\gamma$-GCS gene-transduced tobacco plants accumulated a greater amount of Cd, i.e., $51.38 \mu \mathrm{g} / \mathrm{g}$ in the roots and $11.36 \mu \mathrm{g} / \mathrm{g}$ in leaves. Our experimental results that the overexpression of the enzymatic synthesis gene in the glutathione synthesis pathway would enhance the accumulation of $\mathrm{Cd}$. In addition, our results showed that $\mathrm{Cd}$ concentrations in the leaves of both wild and transgenic tobacco plants were lower than those in the roots. 


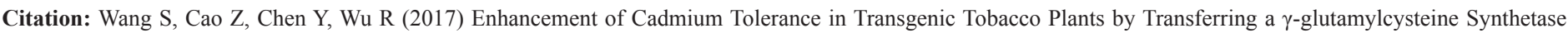
Gene. J Agr Agri Aspect: JAAA-118.

\begin{tabular}{|c|c|}
\hline \multirow{2}{*}{$\gamma$-GCS } & 5'-TACAGGTCCGAAGCATCA-3' \\
\cline { 2 - 2 } & 5'-GGAGATACGACATTACGAGAA-3' \\
\hline \multirow{2}{*}{ Actin } & 5'-AAGGGATGCGAGGATGGA-3' \\
\cline { 2 - 2 } & 5'-CAAGGAAATCACCGCTTTGG-3' \\
\hline
\end{tabular}

Table 1: Sequences of gene-specific primers used for RT-PCR.

\begin{tabular}{|c|c|c|c|}
\hline Samples & $\begin{array}{c}\text { Cd content } \\
(\mathbf{u g} / \mathbf{g})\end{array}$ & $\begin{array}{c}\mathbf{5 \%} \text { Significant } \\
\text { level }\end{array}$ & $\begin{array}{c}\mathbf{1 \%} \text { Significant } \\
\text { level }\end{array}$ \\
\hline $1-1$ & $20.88 \pm 0.77$ & $\mathrm{~b}$ & $\mathrm{~B}$ \\
\hline $1-2$ & $51.38 \pm 1.55$ & $\mathrm{a}$ & $\mathrm{A}$ \\
\hline $2-1$ & $9.95 \pm 0.33$ & $\mathrm{c}$ & $\mathrm{C}$ \\
\hline $2-2$ & $11.36 \pm 0.72$ & $\mathrm{c}$ & $\mathrm{C}$ \\
\hline *1-1: wild tobacco roots; $1-2: \gamma$-GCS transgenic tobacco roots; $2-1:$ \\
wild tobacco leaves; $2-2: \gamma$-GCS transgenic tobacco leaves. $(\mathrm{n}=3)$ \\
\hline
\end{tabular}

Table 2: Statistical analysis of $\mathrm{Cd}$ content in tobacco plants under $\mathrm{Cd}$ stress $(100 \mu \mathrm{mol} / \mathrm{L})$.

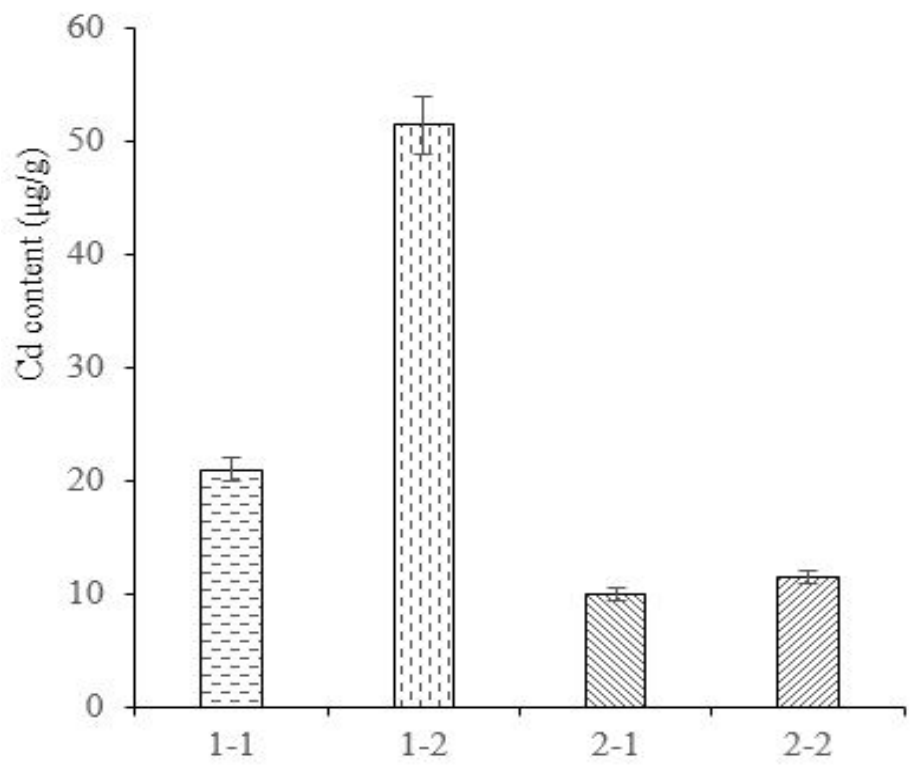

Figure 8: $\mathrm{Cd}$ content of tobacco plants under $\mathrm{Cd}$ stress, i.e., $100 \mu \mathrm{mol} / \mathrm{L}$ Cd solution. Notes: 1) 1-1: wild tobacco roots; 1-2: $\gamma$-GCS transgenic tobacco roots; 2-1: wild tobacco leaves; 2-2: $\gamma$-GCS transgenic tobacco leaves. 2) Bars denote standard error of the mean $(n=3)$ for the biological replicates.

\section{$\gamma$-GCS transgenic tobacco shows enhanced resistance of physiological indexes}

\section{Enzymatic activity}

SOD

SOD is an active substance in living bodies that can eliminate harmful substances in metabolic processes. This enzyme can withstand and block the damage caused to cells by oxygen free radicals, repair damaged cells, and eliminate radicals that cause cell damage. The mechanism of action of SOD is that this enzyme catalyzes the following reaction: $2 \mathrm{O}^{2-}+2 \mathrm{H}^{+} \rightarrow \mathrm{H}_{2} \mathrm{O}_{2}+\mathrm{O}_{2}$. The $\mathrm{H}_{2} \mathrm{O}_{2}$ is further degraded by other enzymes in vivo. Our results (Figure 9 and Table 3 ) showed that the activity of SOD in the roots was relatively low compared with that in the leaves. Transgenic tobacco with $\gamma$-GCS exhibited an increase in the activity of SOD compared with the wild tobacco, i.e., $17.53 \%$ and $16.76 \%$ in the root and leaves, respectively. Because the plants were cultured under the same conditions, the expression of an exogenous gene is the most obvious factor to be considered when analyzing these results. The increase in the activity of the SOD enzyme was mainly due to the expression of the transduction gene.

\begin{tabular}{|c|c|c|c|}
\hline Samples & $\begin{array}{c}\text { Enzyme activ- } \\
\text { ity (U/g } \cdot \mathbf{m i n})\end{array}$ & $\begin{array}{c}\mathbf{5 \%} \text { Significant } \\
\text { level }\end{array}$ & $\begin{array}{c}\mathbf{1 \%} \text { Significant } \\
\text { level }\end{array}$ \\
\hline $1-1$ & $93.03 \pm 3.79$ & $\mathrm{~d}$ & $\mathrm{D}$ \\
\hline $1-2$ & $109.34 \pm 3.88$ & $\mathrm{c}$ & $\mathrm{C}$ \\
\hline $2-1$ & $154.74 \pm 4.38$ & $\mathrm{~b}$ & $\mathrm{~B}$ \\
\hline $2-2$ & $180.68 \pm 4.58$ & $\mathrm{a}$ & $\mathrm{A}$ \\
\hline *1-1: wild tobacco roots; $1-2: \gamma$-GCS transgenic tobacco roots; $2-1:$ \\
wild tobacco leaves; $2-2: \gamma$-GCS transgenic tobacco leaves. $(\mathrm{n}=3)$ \\
\hline
\end{tabular}

Table 3: Statistical analysis of SOD enzyme activity in tobacco plants under Cd stress.

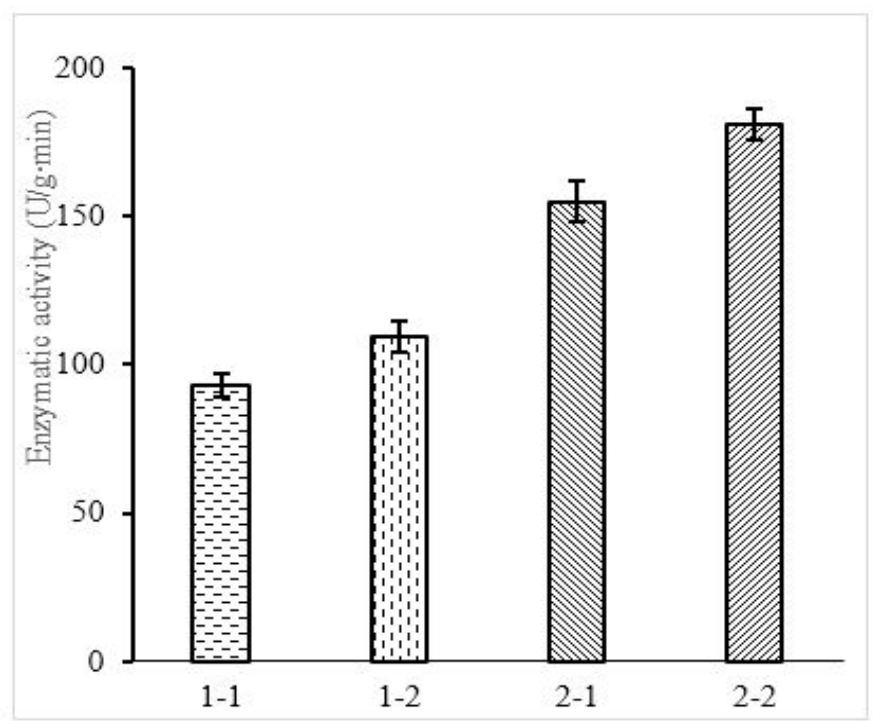

Figure 9: SOD enzymatic activity of tobacco plants under Cd stress. Notes: 1) 1-1: wild tobacco roots; 1-2: $\gamma$-GCS transgenic tobacco roots; 2-1: wild tobacco leaves; 2-2: $\gamma$-GCS transgenic tobacco leaves. 2) Bars denote standard error of the mean $(n=3)$ for the biological replicates.

POD

POD is an important plant enzyme that scavenges active 


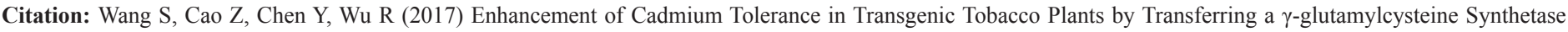
Gene. J Agr Agri Aspect: JAAA-118.

oxygen; it plays an important role in plants in the degradation of $\mathrm{H}_{2} \mathrm{O}_{2}$ and other peroxides into harmless substances such as $\mathrm{H} 2 \mathrm{O}$ and $\mathrm{O} 2$ to maintain a low level of reactive oxygen, which protects the cell membrane structure and thereby improves plant resistance to adverse conditions, stresses and diseases. As shown in Figure 10 and Table 4, the POD enzyme activities of the transgenic tobacco plants were higher than those of wild tobacco. Compared with wild tobacco, the increase in the POD activities in the roots and leaves of the $\gamma$-GCS transgenic tobacco was $32.36 \%$ and $52.28 \%$, respectively.

\begin{tabular}{|c|c|c|c|}
\hline Samples & $\begin{array}{c}\text { Enzyme activ- } \\
\text { ity (U/g } \cdot \mathbf{m i n})\end{array}$ & $\begin{array}{c}\mathbf{5 \%} \text { Significant } \\
\text { level }\end{array}$ & $\begin{array}{c}\mathbf{1 \%} \text { Significant } \\
\text { level }\end{array}$ \\
\hline $1-1$ & $112.03 \pm 3.35$ & $\mathrm{~d}$ & $\mathrm{D}$ \\
\hline $1-2$ & $148.29 \pm 6.11$ & $\mathrm{c}$ & $\mathrm{C}$ \\
\hline $2-1$ & $202.34 \pm 6.39$ & $\mathrm{~b}$ & $\mathrm{~B}$ \\
\hline $2-2$ & $308.78 \pm 8.87$ & $\mathrm{a}$ & $\mathrm{A}$ \\
\hline *1-1: wild tobacco roots; $1-2: \boldsymbol{\gamma}$-GCS transgenic tobacco roots; $2-1:$ \\
wild tobacco leaves; $2-2: \gamma$-GCS transgenic tobacco leaves. $(\mathrm{n}=3)$ \\
\hline
\end{tabular}

Table 4: Statistical analysis of POD enzyme activity in tobacco plants under $\mathrm{Cd}$ stress.

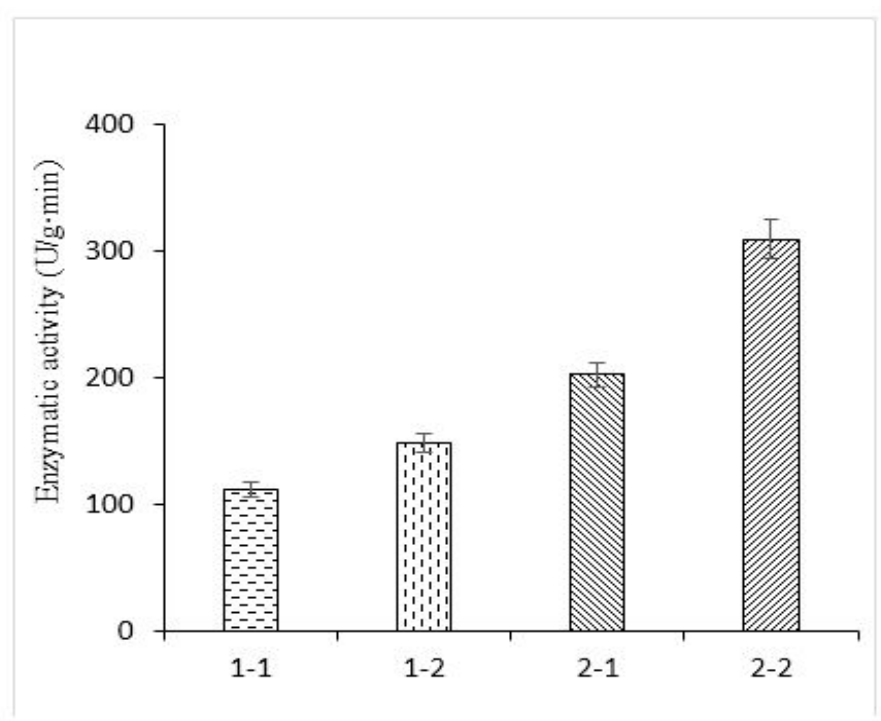

Figure 10: POD enzymatic activity of tobacco plants under Cd stress. Notes: 1) 1-1: wild tobacco roots; 1-2: $\gamma$-GCS transgenic tobacco roots; 2-1: wild tobacco leaves; 2-2: $\gamma$-GCS transgenic tobacco leaves. 2) Bars denote standard error of the mean $(n=3)$ for the biological replicates.

MDA

MDA is a product that is produced when plant organs undergo senescence or are subjected to stress conditions that lead to membrane lipid peroxidation. MDA is usually used as an indicator of lipid peroxidation to determine the degree of cell membrane response to lipid oxidation and stress conditions. The experimental results (Figure 11 and Table 5) show that both the roots and leaves of transgenic tobacco plants had relatively higher concentrations of MDA. Although the amount of MDA produced in root produced was small, it was enhanced by the transduction of the $\gamma$-GCS gene. there was $36.28 \%$ more MDA in the $\gamma$-GCS transgenic tobacco root than that in wild tobacco root. While in the leaves, the MDA content in $\gamma$-GCS transgenic tobacco surpass that in wild tobacco by $11.92 \%$.

\begin{tabular}{|c|c|c|c|}
\hline Samples & $\begin{array}{c}\text { Content } \\
(\boldsymbol{\mu m o l} / \mathbf{g})\end{array}$ & $\begin{array}{c}\mathbf{5 \%} \text { Significant } \\
\text { level }\end{array}$ & $\begin{array}{c}\mathbf{1 \%} \text { Significant } \\
\text { level }\end{array}$ \\
\hline $1-1$ & $3.28 \pm 0.12$ & $\mathrm{~d}$ & $\mathrm{D}$ \\
\hline $1-2$ & $4.47 \pm 0.37$ & $\mathrm{c}$ & $\mathrm{C}$ \\
\hline $2-1$ & $7.13 \pm 0.37$ & $\mathrm{~b}$ & $\mathrm{~B}$ \\
\hline $2-2$ & $7.98 \pm 0.28$ & $\mathrm{a}$ & $\mathrm{A}$ \\
\hline *1-1: wild tobacco roots; $1-2: \gamma$-GCS transgenic tobacco roots; $2-1:$ \\
wild tobacco leaves; $2-2: \gamma$-GCS transgenic tobacco leaves. $(\mathrm{n}=3)$ \\
\hline
\end{tabular}

Table 5: Statistical analysis of MDA content in tobacco plants under $\mathrm{Cd}$ stress.

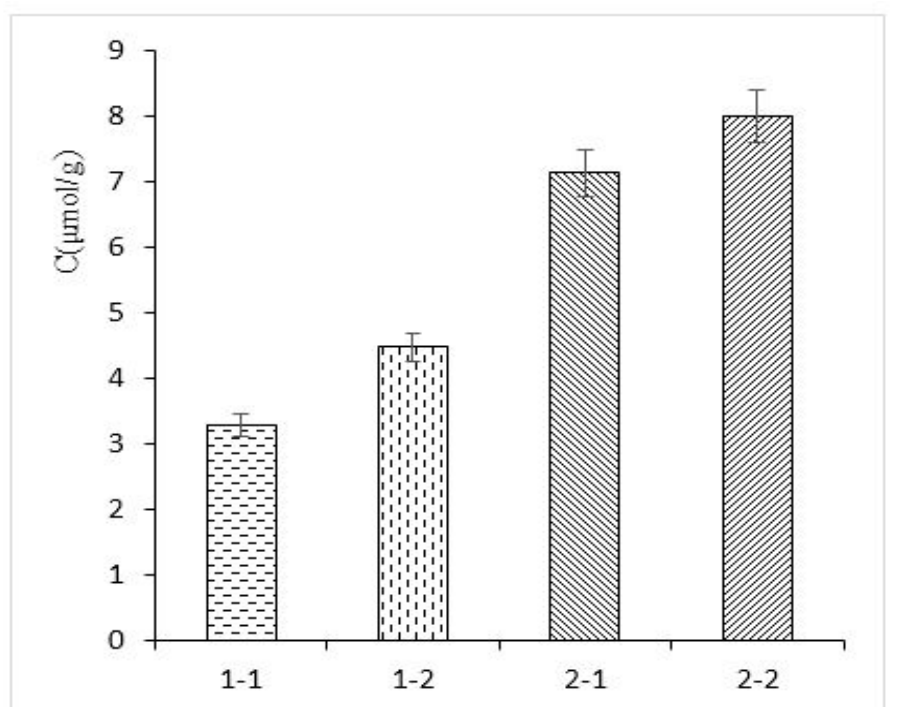

Figure 11: Results the MDA concentration in tobacco plants under $\mathrm{Cd}$ stress. Notes: 1) 1-1: wild tobacco roots; 1-2: $\gamma$-GCS transgenic tobacco roots; 2-1: wild tobacco leaves; 2-2: $\gamma$-GCS transgenic tobacco leaves. 2) Bars denote standard error of the mean $(n=3)$ for the biological replicates.

\section{Proline}

Proline is one component of plant protein that can dissociate and become widespread in plant tissue. Under stress conditions such as drought and salinity, many plants accumulate a large amount of proline. The proline accumulated in plant bodies can play a role in cytoplasm osmotic adjustment, as well as a critical role in stabilizing the structure of biological macromolecules, reducing the acidity of cells, alleviating ammonia poisoning as 


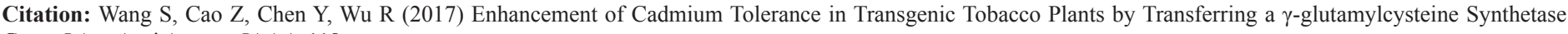
Gene. J Agr Agri Aspect: JAAA-118.

well as regulating the cellular oxidation reduction potential, and so on. The proline content (Fig. 12 and Table 6) in our experiments showed that the transgenic tobacco $\gamma$-GCS gene was enhanced by the expression of proline. The proline content in wild tobacco was $2.74 \mu \mathrm{mol} / \mathrm{g}$ in the root and $53.98 \mu \mathrm{mol} / \mathrm{g}$ in the leaves compared with $3.07 \mu \mathrm{mol} / \mathrm{g}$ and $79.72 \mu \mathrm{mol} / \mathrm{g}$ in the roots and leaves, respectively, of $\gamma$-GCS transgenic tobacco plants. The transgenic tobacco plants accumulated more proline in the both roots $(12.04 \%)$ and leaves $(47.68 \%)$ when compared with the wild tobacco plants.

\begin{tabular}{|c|c|c|c|}
\hline Samples & $\begin{array}{c}\text { Concentration } \\
(\mu \mathrm{mol} / \mathrm{g})\end{array}$ & $\begin{array}{c}5 \% \text { Significant } \\
\text { level }\end{array}$ & $\begin{array}{c}\text { 1\% Signifi- } \\
\text { cant level }\end{array}$ \\
\hline $1-1$ & $2.74 \pm 0.08$ & $\mathrm{c}$ & $\mathrm{C}$ \\
\hline $1-2$ & $3.07 \pm 0.22$ & $\mathrm{c}$ & $\mathrm{C}$ \\
\hline $2-1$ & $53.98 \pm 0.79$ & $\mathrm{~b}$ & $\mathrm{~B}$ \\
\hline $2-2$ & $79.72 \pm 1.57$ & $\mathrm{a}$ & $\mathrm{A}$ \\
\hline
\end{tabular}

*1-1: wild tobacco roots; 1-2: $\gamma$-GCS transgenic tobacco roots; $2-1$ : wild tobacco leaves; 2-2: $\gamma$-GCS transgenic tobacco leaves. $(n=3)$

Table 6: Statistical analysis of proline content in tobacco plants under Cd stress.

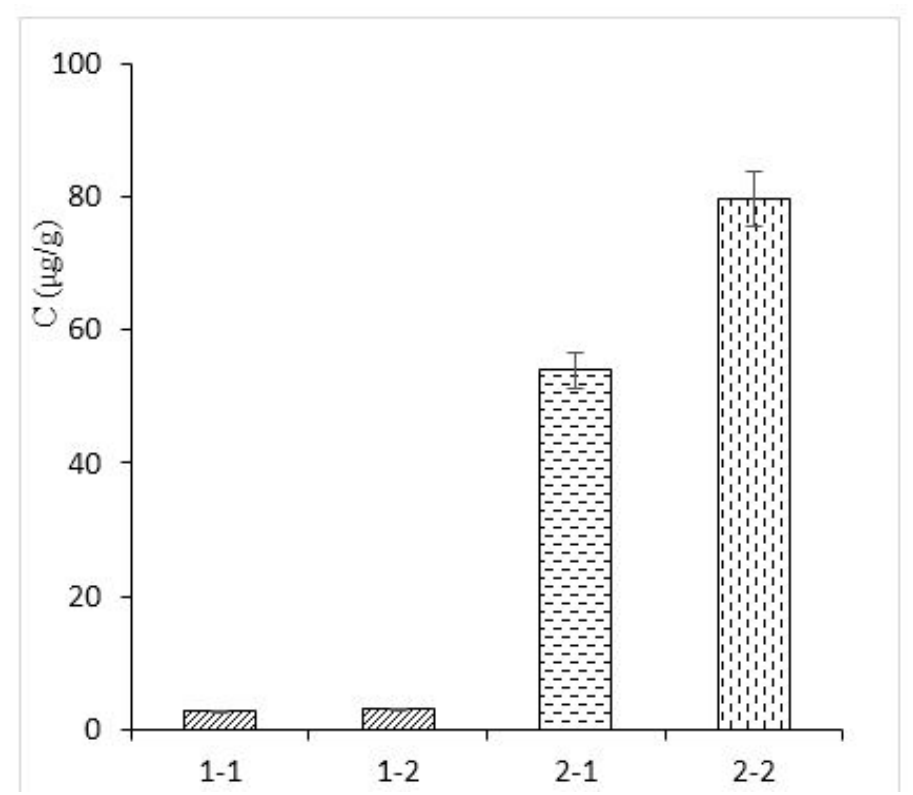

Figure 12: Results of the proline content in tobacco plants under Cd stress. Notes: 1) 1-1: wild tobacco roots; 1-2: $\gamma$-GCS transgenic tobacco roots; 2-1: wild tobacco leaves; 2-2: $\gamma$-GCS transgenic tobacco leaves. 2) Bars denote standard error of the mean $(n=3)$ for the biological replicates.

\section{Glutathione (GSH)}

The GSH measured in the roots and leaves of the transgenic and wild tobacco plants is shown in Fig. 13 and Table 7. The GSH content in the transgenic tobacco plants was higher than that measured in the wild tobacco plants, in both roots and leaves. The GSH in the roots and leaves of the $\gamma$-GCS transgenic tobacco plants was
$13.41 \%$ and $29.45 \%$ higher, respectively, than that in wild plants. GSH is a substrate of PCs, and influences the amount of PCs formation. PCs can reduce the $\mathrm{Cd}$ toxicity of plants through chelation in the form of $\mathrm{Cd}^{2+}$, and thereby play an important role in heavy metal detoxification. The results in this study showed that under $\mathrm{Cd}^{2+}$ stress, the $\gamma$-GCS gene-transduced tobacco plants had higher GSH contents compared with the wild tobacco plants. This suggests that the exogenous genes were expressed in tobacco plants, which enhanced the synthesis of GSH and led to a greater amount of PCs and a higher accumulation of the heavy metal.

\begin{tabular}{|c|c|c|c|}
\hline Samples & Concentration $(\mu \mathrm{mol} / \mathrm{g})$ & $\begin{array}{c}5 \% \text { Signifi- } \\
\text { cant level }\end{array}$ & $\begin{array}{c}1 \% \text { Signifi- } \\
\text { cant level }\end{array}$ \\
\hline $1-1$ & $35.86 \pm 1.67$ & $\mathrm{~b}$ & $\mathrm{~B}$ \\
\hline $1-2$ & $40.67 \pm 1.84$ & $\mathrm{a}$ & $\mathrm{A}$ \\
\hline $2-1$ & $20.64 \pm 1.15$ & $\mathrm{~d}$ & $\mathrm{D}$ \\
\hline $2-2$ & $26.72 \pm 1.16$ & $\mathrm{c}$ & $\mathrm{C}$ \\
\hline *1-1: wild tobacco roots; $1-2: \gamma$-GCS transgenic tobacco roots; $2-1:$ \\
wild tobacco leaves; $2-2: \gamma$-GCS transgenic tobacco leaves. $(\mathrm{n}=3)$. \\
\hline
\end{tabular}

Table 7: Statistical analysis of GSH content in tobacco plants under $\mathrm{Cd}$ stress.

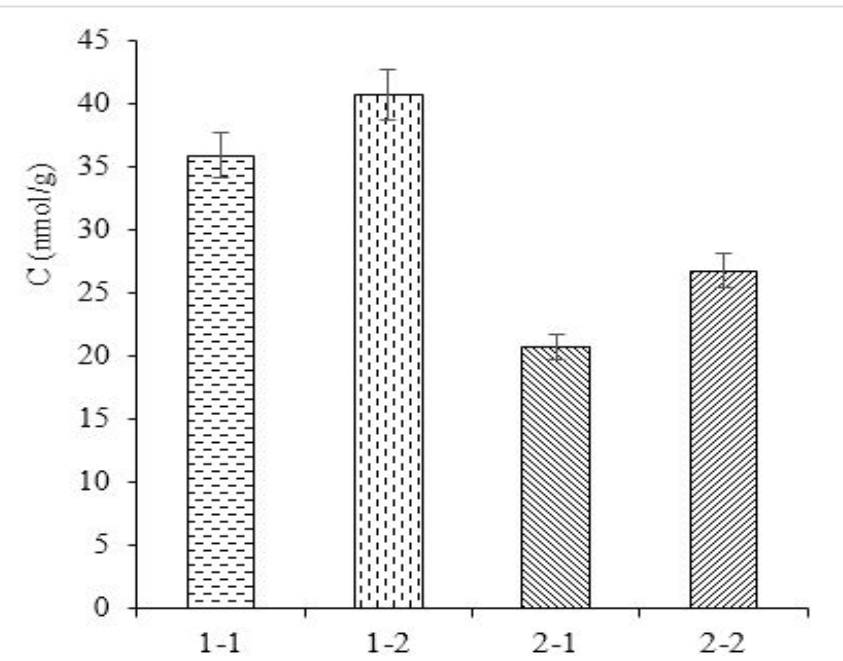

Figure 13: GSH contents of transgenic and non-transgenic tobacco plants under Cd stress. Notes: 1) 1-1: wild tobacco roots; $1-2$ : $\gamma$-GCS transgenic tobacco roots; 2-1: wild tobacco leaves; $2-2: \gamma$-GCS transgenic tobacco leaves. 2) Bars denote standard error of the mean $(n=3)$ for the biological replicates.

\section{Discussion}

Plants develop many defense mechanisms to resist heavy metal stress, one of which is dependent on cysteine-rich peptides, mainly phytochelatins and metallothioneins [27]. These peptides can combine with many types of heavy metals to achieve the function of detoxification $[28,29]$. PC synthase is a key enzyme 


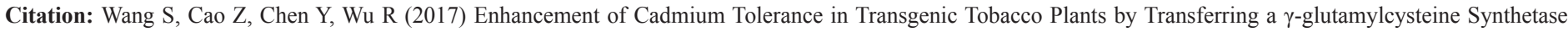
Gene. J Agr Agri Aspect: JAAA-118.

in the biosynthetic pathway; The activity of PC synthase has been known for many years, but its gene was not isolated until 1999 when three research groups cloned the gene of PC synthase of Arabidopsis, wheat, and fission yeast [30]. Since phytochelatin synthase was cloned, it has aroused the attention of researchers $[28,31-33]$; some researchers have used the PC synthase gene to genetically modify plants for improved heavy metal pollution remediation of the environment. Overexpression of the Arabidopsis gene AtPCS1 in tobacco enhanced tobacco seedling resistance to $\mathrm{Cd}$ and increased $\mathrm{Cd}$ accumulation by twofold compared with wild species [23]. Expression of the AtPCS1 gene in E. coli improved the survival rate under cadmium and arsenic stress, and increased the $\mathrm{Cd}$ and arsenic contents in E. coli by 20- and 50-fold [33, 34], respectively.

Resistance testing is an important indicator and is a promising measurement of the anti-reversal mechanism of transgenic tobacco. Through the determination and analysis of the physiological and biochemical indicators of tobacco, this method can be used to ascertain the anti-heavy metal capacity of transgenic tobacco. Heavy metals can directly or indirectly lead to the formation of reactive oxygen in plants, which lead to an increase in free radicals that affect membrane lipid oxidation, proteins, pigments, enzymes, nucleic acids, and may even result in plant death. SOD is an active substance in plants that can eliminate harmful substances produced during metabolic processes $[35,36]$. This enzyme can withstand and block the damage caused to cells by oxygen free radicals, repair damaged cells, and eliminate the radicals that cause cell damage. POD is another important plant enzyme that scavenges active oxygen. This enzyme plays an important role in plants in the degradation of $\mathrm{H}_{2} \mathrm{O}_{2}$ and other peroxides into harmless substances such as $\mathrm{H}_{2} \mathrm{O}$ and $\mathrm{O}_{2}$ to maintain a low level of reactive oxygen, which protects the cell membrane structure and thereby improves plant resistance to adverse conditions, stresses, and diseases [36, 37]. Proline is an important stress response material. From a plant physiology perspective, when plants are stressed, they produce a certain response [38], and the final product of membrane lipid oxidation is MDA. MDA, which combines with the plasma membrane, amino acids, proteins, unsaturated fatty acids and other biological macromolecules, prevents the synthesis of lipids and the destruction of the membrane structure [39]. Therefore, on the one hand, membrane lipid peroxidation can cause DNA damage and change the transport of RNA from the nucleus to the cytoplasm, but on the other hand, can also affect cell membrane structure and function. Therefore, the MDA content is an indicator of lipid oxidation strength [40]. Plants growing in natural soil that accumulate a $\mathrm{Cd}$ content of more than $100 \mathrm{mg} / \mathrm{kg}$ (dry weight) are referred to as $\mathrm{Cd}$ hyperaccumulators. Studies have shown that plants of the Brassicaceae family can accumulate $\mathrm{Cd}$ in their roots and aerial parts. Thlaspi caerulescens is a Cd hyperaccumulator of the Brassicaceae family; it can accumulate as much as 1140 $\mathrm{mg} / \mathrm{kg}$ of $\mathrm{Cd}$ in its aboveground components under the stress of
$200 \mu \mathrm{mol} / \mathrm{L}$ of $\mathrm{Cd}^{2+}[41,42]$. Brassica juncea $\mathrm{L}$. can accumulate 200 to $1200 \mathrm{mg} / \mathrm{kg}$ of $\mathrm{Cd}$ under the stress of $25 \mu \mathrm{mol} / \mathrm{L}$ of $\mathrm{Cd}$ [43]. Many other studies have come to the same conclusions, i.e., that cabbage, especially the aerial parts, has an excellent ability to accumulate $\mathrm{Cd}$ under $\mathrm{Cd}^{2+}$ stress. The $\mathrm{Cd}$ concentration in the cabbage body is related to the concentration of PC and GSH. The hyper-accumulation of $\mathrm{Cd}$ in cabbage is consistent with the acceleration of $\mathrm{PC}$ synthesis induction, indicating that the synthesis of PCs is very important for $\mathrm{Cd}$ hyper-accumulators. On the other hand, the increase in PC synthesis due to Cd stress would accelerate the enrichment of GSH in the cell. However, under a high $\mathrm{Cd}$ concentration of $200 \mu \mathrm{mol} / \mathrm{L}$, PCs seem to be saturated by $\mathrm{Cd}$, while the GSH concentration declines, and the amount of in vivo accumulation of $\mathrm{Cd}$ in cabbage exceeds its $\mathrm{Cd}$ detoxification capacity [44]. In the biosynthetic pathway of the roots, the concentration of PCs under Cd stress is related to the biosynthetic pathway.

\section{Conclusion}

Our experimental results showed that the $\gamma$-GCS transgenic tobacco plants demonstrated a superior ability with respect to cadmium stress resistance and accumulation, and there was a relative high accumulation of cadmium in the roots compared with that in the leaves. The results indicate that the transduction of the exogenous resistance gene $\gamma$-GCS enhanced the $\mathrm{Cd}^{2+}$ resistance and accumulation of plants, and is a potential remediation method for heavy metal pollution. Based on this experiment, further studies should be conducted. Firstly, the selection range of materials should be expanded and the determination of the physiological indicators should be improved by systematically measuring the physiological responses of plants under heavy metal stress. Screening of plant germplasm resources and in-depth analyses of the physiological and biochemical indicators in different plant genotypes should be conducted to obtain better and more heavy metal resistancerelated plant materials. Secondly, the cloning of other genes in the PC synthesis and MT metabolic pathways should be completed. In addition, an in-depth study of their mechanisms of action is required to provide a good foundation to enrich and improve the PC metabolic pathways. Thirdly, a cabbage Cd-stress cDNA library should be constructed to provide materials for the further study of cabbage heavy metal resistance. Fourthly, the numerous existing wild-type Chinese cabbage germplasm resources, or the relevant gene deletion cabbage germplasm resources should be obtained using appropriate techniques.

\section{Declarations}

\section{Acknowledgements}

We are grateful to Dr. Jason T.C. Tzen, professor of Graduate institute of biotechnology, Taiwan Chung Hsing University for his kind editing in our manuscript. 


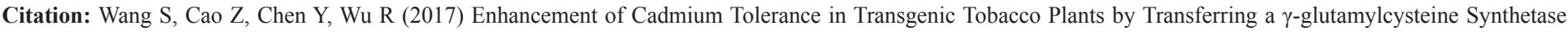
Gene. J Agr Agri Aspect: JAAA-118.

\section{Funding}

This work was supported by the National Natural Science Foundation of China (grants No.30571138) and the pivotal project in the Natural Science Foundation of Fujian Province in China (grants No. B0520001).

Availability of data and materials

All the supporting data are included within the article and additional files.

\section{Authors' contribution}

SW, ZC, YC contributed to the design of the research. YC carried out the $\gamma$-GCS gene isolation and analysis. ZC carried out the generation of transgenic tobacco plant and the physiological analysis. ZC, RW and YC contributed to the analysis of the results and writing the manuscript. SW supervised the research and contributed to the correction of the manuscript. All authors have read and approved the final version of the manuscript.

\section{Competing interests}

The authors declare that they have no competing interests.

\section{Consent for publication}

Not applicable.

\section{Ethics approval and consent to participate}

Not applicable

\section{References}

1. Zhang Y, Zhao L, Wang Y, Yang B, Chen S (2008) Enhancement of heavy metal accumulation by tissue specific co-expression of iaaM and ACC deaminase genes in plants. Chemosphere 72: 564-571.

2. Wernick IK, Themelis NJ (1998) Recycling metals for the environment. Annual Review of Energy and the Environment 23: 465-497.

3. Zhuang P, McBride MB, Xia H, Li N, Li Z (2009) Health risk from heavy metals via consumption of food crops in the vicinity of Dabaoshan mine, South China. Science of the Total Environment 407: 1551-1561.

4. Van Huysen T, Terry N, Pilon-Smits EA (2004) Exploring the selenium phytoremediation potential of transgenic Indian mustard overexpressing ATP sulfurylase or cystathionine-gamma-synthase. Int J Phytoremediation 6: 111-118.

5. Kotrba P, Najmanova J, Macek T, Ruml T, Mackova M (2009) Genetically modified plants in phytoremediation of heavy metal and metalloid soil and sediment pollution. Biotechnol Adv 27: 799-810.

6. Eapen S, Singh S, D'souza S (2007) Advances in development of transgenic plants for remediation of xenobiotic pollutants. Biotechnology advances 25: 442-451.

7. Van Aken B (2009) Transgenic plants for enhanced phytoremediation of toxic explosives. Curr Opin Biotechnol 20: 231-236.
8. Bizily SP, Rugh CL, Summers AO, Meagher RB (1999) Phytoremediation of methylmercury pollution: merB expression in Arabidopsis thaliana confers resistance to organomercurials. Proceedings of the National Academy of Sciences 96: 6808-6813.

9. Clemens S, Palmgren MG, Krämer U (2002) A long way ahead: understanding and engineering plant metal accumulation. Trends in plant science 7: 309-315.

10. Pal R, Rai J (2010) Phytochelatins: peptides involved in heavy metal detoxification. Applied biochemistry and biotechnology 160: 945-963.

11. Daniell H, Ruiz ON, Dhingra A (2004) Chloroplast genetic engineering to improve agronomic traits. Transgenic plants: methods and protocols 286: 111-137.

12. Song W-Y, Sohn EJ, Martinoia E, Lee YJ, Yang Y-Y, et al. (2003) Engineering tolerance and accumulation of lead and cadmium in transgenic plants. Nature biotechnology 21: 914-919.

13. Peterson AG, Oliver DJ (2006) Leaf-targeted phytochelatin synthase in Arabidopsis thaliana. Plant Physiology and Biochemistry 44: 885892.

14. Cobbett C, Goldsbrough P (2002) Phytochelatins and metallothioneins: roles in heavy metal detoxification and homeostasis. Annual review of plant biology 53: 159-182.

15. Wang S-L, Chen X-Y, Chen H, Chen D-M, Wang F-J, et al. (2007) Physio-chemical mechanism of cadmium tolerance of Chinese cabbage (Brassica chinensis). Chinese Journal of Eco-Agriculture 5: P029.

16. Cobbett CS, May MJ, Howden R, Rolls B (1998) The glutathione-deficient, cadmium-sensitive mutant, cad2-1, of Arabidopsis thalianais deficient in ?-glutamylcysteine synthetase. The Plant Journal 16: 7378.

17. Dai J, Balish R, Meagher RB, Merkle SA (2009) Development of transgenic hybrid sweetgum (Liquidambar styracifluax L. formosana) expressing ?-glutamylcysteine synthetase or mercuric reductase for phytoremediation of mercury pollution. New forests 38 : $35-52$.

18. Reisinger S, Schiavon M, Terry N, Pilon-Smits EA (2008) Heavy metal tolerance and accumulation in Indian mustard (Brassica juncea L.) expressing bacterial ?-glutamylcysteine synthetase or glutathione synthetase. International Journal of Phytoremediation 10: 440-454.

19. Scheerer U, Haensch R, Mendel RR, Kopriva S, Rennenberg H, et al (2010) Sulphur flux through the sulphate assimilation pathway is differently controlled by adenosine 5'-phosphosulphate reductase under stress and in transgenic poplar plants overexpressing ?-ECS, SO, or APR. Journal of experimental botany 61: 609-622.

20. Ghanta S, Bhattacharyya D, Sinha R, Banerjee A, Chattopadhyay S (2011) Nicotiana tabacum overexpressing ?-ECS exhibits biotic stress tolerance likely through NPR1-dependent salicylic acid-mediated pathway. Planta 233: 895-910.

21. Guo J, Dai X, Xu W, Ma M (2008) Overexpressing GSH1 and AsPCS1 simultaneously increases the tolerance and accumulation of cadmium and arsenic in Arabidopsis thaliana. Chemosphere 72: 1020-1026.

22. Kawashima CG, Noji M, Nakamura M, Ogra Y, Suzuki KT, Saito K (2004) Heavy metal tolerance of transgenic tobacco plants over-expressing cysteine synthase. Biotechnology letters 26: 153-157. 
Citation: Wang S, Cao Z, Chen Y, Wu R (2017) Enhancement of Cadmium Tolerance in Transgenic Tobacco Plants by Transferring a $\gamma$-glutamylcysteine Synthetase Gene. J Agr Agri Aspect: JAAA-118.

23. Pomponi M, Censi V, Di Girolamo V, De Paolis A, Di Toppi LS, et al. (2006) Overexpression of Arabidopsis phytochelatin synthase in tobacco plants enhances Cd2+ tolerance and accumulation but not translocation to the shoot. Planta 223: 180-190.

24. Oh K, Cheon BY, Cho SH, Truong HQ, Ok SH, et al. (2003) Expression of the bovine growth hormone alters the root morphology in transgenic tobacco plants. Transgenic research 12: 363-367.

25. Edwards K, Johnstone C, Thompson C (1991) A simple and rapid method for the preparation of plant genomic DNA for PCR analysis. Nucleic acids research 19: 1349.

26. L L (2009) Laboratory Manual Guidances of Plant Physiology Module Beijing: Science Press.

27. Rai PK (2010) Phytoremediation of heavy metals in a tropical impoundment of industrial region. Environmental monitoring and assessment 165: 529-537.

28. Gasic K and Korban SS (2007) Expression of Arabidopsis phytochelatin synthase in Indian mustard (Brassica juncea) plants enhances tolerance for Cd and Zn. Planta 225: 1277-1285.

29. Shukla D, Kesari R, Mishra S, Dwivedi S, Tripathi RD, et al. (2012) Expression of phytochelatin synthase from aquatic macrophyte Ceratophyllum demersum $\mathrm{L}$. enhances cadmium and arsenic accumulation in tobacco. Plant cell reports 31: 1687-1699.

30. Ha S-B, Smith AP, Howden R, Dietrich WM, Bugg S, et al. (1999) Phytochelatin synthase genes from Arabidopsis and the yeast Schizosaccharomyces pombe. The Plant Cell 11: 1153-1163.

31. Ammar WB, Mediouni C, Tray B, Ghorbel M, Jemal F (2008) Glutathione and phytochelatin contents in tomato plants exposed to cadmium. Biologia plantarum 52: 314-320.

32. Dong R, Formentin E, Losseso C, Carimi F, Benedetti P, et al. (2005) Molecular cloning and characterization of a phytochelatin synthase gene, PvPCS1, from Pteris vittata L. Journal of Industrial Microbiology and Biotechnology 32: 527-533.

33. Gasic K and Korban SS (2007) Transgenic Indian mustard (Brassica juncea) plants expressing an Arabidopsis phytochelatin synthase (AtPCS1) exhibit enhanced As and Cd tolerance. Plant molecular biology 64: 361-369.

34. Sauge-Merle S, Cuiné S, Carrier P, Lecomte-Pradines C, Luu D-T, et al. (2003) Enhanced toxic metal accumulation in engineered bacterial cells expressing Arabidopsis thaliana phytochelatin synthase. Applied and Environmental Microbiology 69: 490-494.
35. Foyer CH, Lopez-Delgado H, Dat JF, Scott IM (1997) Hydrogen peroxide-and glutathione-associated mechanisms of acclimatory stress tolerance and signalling. Physiologia Plantarum 100: 241-254.

36. Gorinova N, Nedkovska M, Todorovska E, Simova-Stoilova L, Stoyanova Z, et al. (2007) Improved phytoaccumulation of cadmium by genetically modified tobacco plants (Nicotiana tabacum L.). Physiological and biochemical response of the transformants to cadmium toxicity. Environmental Pollution 145: 161-170.

37. Prasad TK, Anderson MD, Martin BA, Stewart CR (1994) Evidence for Chilling-Induced Oxidative Stress in Maize Seedlings and a Regulatory Role for Hydrogen Peroxide. Plant Cell 6: 65-74.

38. Siripornadulsil S, Traina S, Verma DPS, Sayre RT (2002) Molecular mechanisms of proline-mediated tolerance to toxic heavy metals in transgenic microalgae. The Plant Cell 14: 2837-2847.

39. Shah K, Kumar RG, Verma S, Dubey R (2001) Effect of cadmium on lipid peroxidation, superoxide anion generation and activities of antioxidant enzymes in growing rice seedlings. Plant Science 161: 11351144

40. Ishikawa S, Noriharu A, Murakami M, Wagatsuma T (2006) Is Brassica juncea a suitable plant for phytoremediation of cadmium in soils with moderately low cadmium contamination?-Possibility of using other plant species for Cd-phytoextraction. Soil Science and Plant Nutrition 52: $32-42$.

41. Babula P, Adam V, Havel L, Kizek R (2012) Cadmium accumulation by plants of Brassicaceae family and its connection with their primary and secondary metabolism. In: The plant family Brassicaceae. Springer 21: 71-97.

42. Chassaigne H, Vacchina V, Kutchan TM, Zenk MH (2001) Identification of phytochelatin-related peptides in maize seedlings exposed to cadmium and obtained enzymatically in vitro. Phytochemistry 56: 657668.

43. Brown S, Angle J, Chaney R, Baker A (1995) Zinc and cadmium uptake by hyperaccumulator Thlaspi caerulescens grown in nutrient solution. Soil Science Society of America Journal 59: 125-133.

44. Keller A, Schulin R (2003) Modelling heavy metal and phosphorus balances for farming systems. Nutrient cycling in agroecosystems 66: 271-284. 